Volume 3

Issue 4 -- Cardiovascular Aging

Article 5

$11-11-2016$

\title{
Functional Alterations of Ion Channels From Cardiac Fibroblasts in Heart Diseases
}

Gracious R. Ross

Arshad Jahangir

Follow this and additional works at: https://aah.org/jpcrr

Part of the Cardiovascular Diseases Commons, Cardiovascular System Commons, and the Medical Molecular Biology Commons

\section{Recommended Citation}

Ross GR, Jahangir A. Functional alterations of ion channels from cardiac fibroblasts in heart diseases. J Patient Cent Res Rev. 2016;3:207-16. doi: 10.17294/2330-0698.1411

Published quarterly by Midwest-based health system Advocate Aurora Health and indexed in PubMed Central, the Journal of Patient-Centered Research and Reviews (JPCRR) is an open access, peer-reviewed medical journal focused on disseminating scholarly works devoted to improving patient-centered care practices, health outcomes, and the patient experience. 


\title{
Functional Alterations of Ion Channels From Cardiac Fibroblasts in Heart Diseases
}

\author{
Gracious R. Ross, PhD, Arshad Jahangir, MD \\ Sheikh Khalifa bin Hamad Al Thani Center for Integrative Research on Cardiovascular Aging, Aurora Research \\ Institute, Aurora Health Care, Milwaukee, WI
}

\begin{abstract}
In an aged population, cardiovascular disease is the leading cause of fatality and morbidity. Age-related fibrotic remodeling of the heart contributes to progressive myocardial dysfunction. Cardiac fibroblasts (CF), responsible for the maintenance of extracellular matrix and fibrosis process, play an important role in cardiac health and disease. CFs influence myocardial function by their chemical, electrical and mechanical interactions with cardiomyocytes through extracellular matrix deposition or secretion of cytokines and growth factors. These, in turn, are modulated by ion channels, macromolecular pores in the plasma membrane that allow selective ionic fluxes of major ions like $\mathrm{K}^{+}, \mathrm{Ca}^{2+}, \mathrm{Na}^{+}$or $\mathrm{Cl}^{-}$, which affect membrane potential and cellular signal transduction. The importance of ion channels in modulating various functions of CFs, including proliferation, differentiation, secretion and apoptosis, is being recognized from recent studies of CFs from animal models and tissue from patients with various cardiac pathologies. Understanding the role of ion channels in CFs under physiological conditions and their alterations in age-related cardiac diseases may help facilitate development of novel therapeutic strategies to limit cardiac fibrosis and its adverse effect on myocardial function. This narrative review summarizes the knowledge gained thus far on ion channels in CFs and their relationship with cardiac diseases in human and experimental animal models. (J Patient Cent Res Rev. 2016;3:207-216.)
\end{abstract}

Keywords ion channels; cardiac fibroblasts; heart diseases; aging

Cardiovascular disease is the leading cause of morbidity and mortality in the aged population. ${ }^{1}$ It is influenced by age-related fibrotic remodeling of the heart, which contributes to progressive myocardial dysfunction as demonstrated in various experimental and clinical studies. ${ }^{2}$ Cardiac fibroblasts (CF), responsible for the maintenance of extracellular matrix and fibrosis process, form more than $70 \%$ of the total heart cell population and play an important role in cardiac health and disease. Fibroblasts are mesenchymal cells that secrete extracellular matrix proteins that provide structural framework for tissues, such as collagen and fibronectin, and participate in wound healing after injury. In addition, CFs influence myocardial function by their chemical, electrical and mechanical interactions with cardiomyocytes. ${ }^{3}$ In response to

Correspondence: Arshad Jahangir, MD, 2801 W. Kinnickinnic River Parkway, \#235, Milwaukee, WI, 53215, T: 414-649-3909,

Email: publishing44@aurora.org injury, fibroblasts get activated by local cytokines to migrate and transdifferentiate into more secretory and contractile myofibroblasts. ${ }^{4}$ For detailed information on the role of fibroblasts in cardiac fibrosis, reference the recent review by Travers et al. ${ }^{5}$

Fibroblast function is modulated by various receptors and proteins on the cell surface, including ion channels, macromolecular pores in the cell membrane that allow selective fluxes of major ions $\mathrm{K}^{+}, \mathrm{Ca}^{2+}, \mathrm{Na}^{+}$or $\mathrm{Cl}^{-}$across the plasma membrane, affecting membrane potential and cellular signal transduction. Ion channels in excitable cardiac muscle cells have been well studied and their role in cardiac physiology and pathology well characterized. Of late, the importance of ion channels in CFs, which are considered to be nonexcitable cells, has emerged from recent studies of cardiac pathophysiology using animal models or human tissue. These studies have demonstrated the role of ion channels in modulating various $\mathrm{CF}$ functions such as proliferation, differentiation, secretion and apoptosis. 
Understanding the contribution of different $\mathrm{CF}$ ion channels to physiological responses to stress and their alterations in pathological state may help facilitate development of novel therapeutic strategies to limit fibrosis and its adverse effects on myocardial function. This narrative review summarizes the knowledge gained thus far on ion channels in CFs and their relationship with cardiac diseases in human and experimental animal models.

\section{Potassium ( $\mathrm{K}^{+}$) Channels}

Potassium channels are diverse and tightly regulated, with high selectivity for $\mathrm{K}^{+}$ion permeation. Across plasma membranes of cells, $\mathrm{K}^{+}$ions have negative equilibrium potential, hence opening of $\mathrm{K}^{+}$channels tends to weaken excitation. ${ }^{6} \mathrm{~K}^{+}$channels play various roles in cellular functions, including stabilizing membrane potentials, timing action potential durations in excitable cells, spacing repetitive excitations, and modulating membrane polarity, secretion and contractility as mediated by receptors or intracellular signaling. These channels can be identified by their distinct gating characteristics. ${ }^{6}$ Many of the $\mathrm{K}^{+}$channels have been reported to play important role in $\mathrm{CF}$ functions in healthy and disease states. A summary of the role of $\mathrm{K}^{+}$channels, along with other ion channels, on different functions of CFs in humans is depicted in Figure 1, while Table $1^{7-29}$ reports findings from both human and animal studies.

Voltage-Gated $\mathrm{K}^{+}\left(\mathrm{K}_{v}\right)$ Channels: $\mathrm{K}_{\mathrm{v}}$ channels are highly sensitive to voltage changes across the plasma membrane. Chamber-specific differential expression of $\mathrm{K}_{\mathrm{v}}$ currents is reported in canine CFs to have greater density in the left ventricle than the left atrium. ${ }^{30}$ Downregulation of tetraethylammonium-sensitive $\mathrm{K}_{\mathrm{v}}$ current in atrial fibroblasts from a failing heart has been reported in a canine tachypacing-induced heart

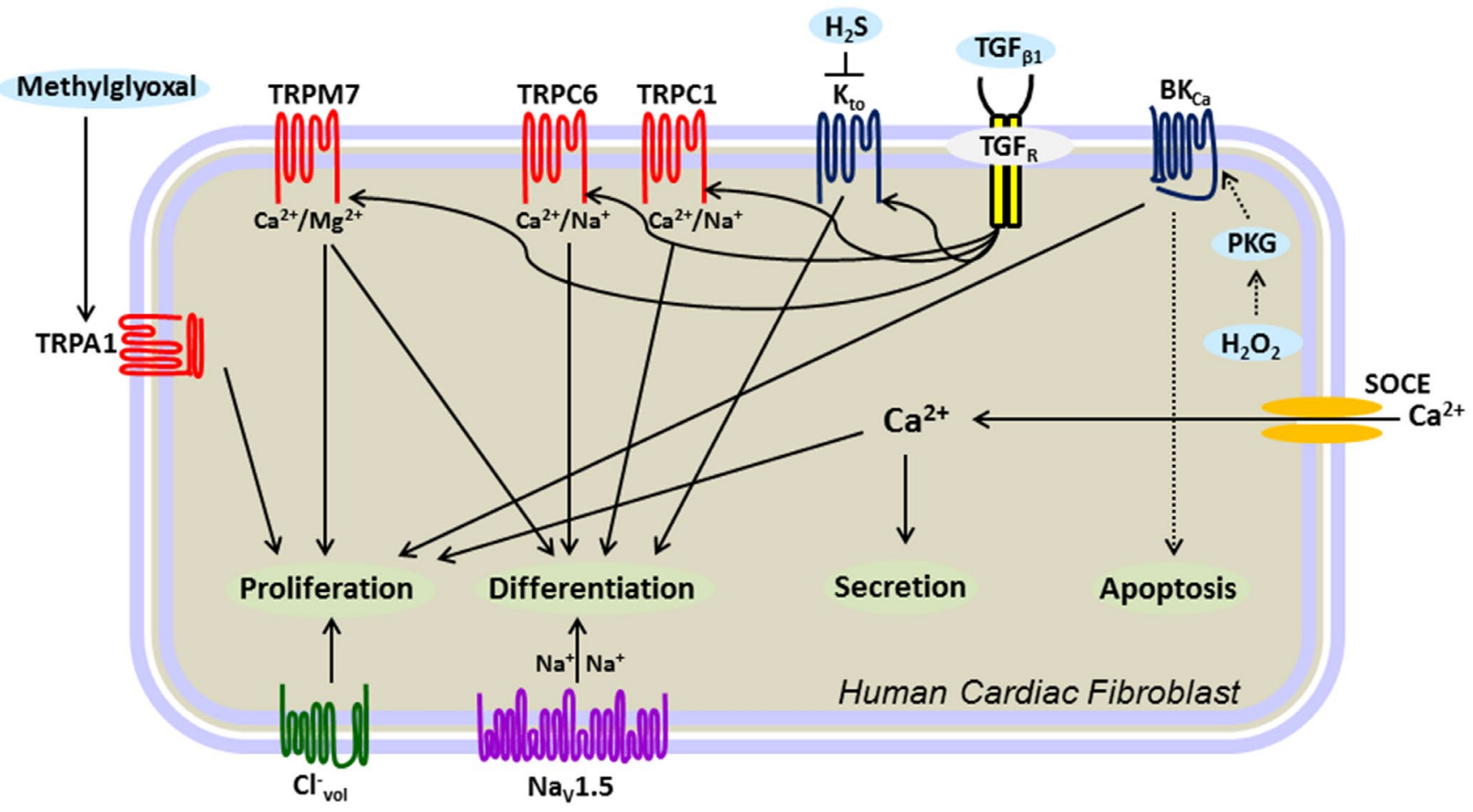

Figure 1. Functional regulation of human cardiac fibroblast by multiple ion channels. The $(\longrightarrow)$ arrow indicates facilitation; the $(\perp)$ symbol indicates inhibition/attenuation; and the $(\cdots \cdots . . \rightarrow)$ arrow indicates the $\mathrm{H}_{2} \mathrm{O}_{2}$-initiated pathway. Transient receptor potential (TRP) channels include TRPC ("canonical"), TRPM ("melastatin") and TRPA ("ankyrin"). SOCE, store-operated $\mathrm{Ca}^{2+}$ entry; PKG, protein kinase G; BKca, big-conductance Ca ${ }^{2+}$-activated potassium channel; $K_{\text {to, }}$ transient outward potassium channel; $\mathrm{Cl}_{\text {vol, }}$ volume-sensitive chloride channels; $\mathrm{Na}_{v} 1.5$, sodium channels (tetrodotoxin-resistant); TGF $\beta 1$, transforming growth factor type $\beta 1 ; T G F_{R}, T G F_{\beta 1}$ receptor; $H_{2} S$, hydrogen sulphide; $\mathrm{H}_{2} \mathrm{O}_{2}$, hydrogen peroxide. 
failure model. This downregulation of $\mathrm{K}_{\mathrm{v}}$ current was reported to be beneficial. Mathematical modeling with assumption of cardiomyocyte-fibroblast electrical coupling demonstrated an antifibrillatory effect of downregulated $\mathrm{K}_{\mathrm{v}}$ currents facilitating termination of electrical reentry by promoting atrial cardiomyocyte depolarization, reduction in $\mathrm{Na}^{+}$channel availability and prolongation of action potential duration. ${ }^{15}$
However, how far these modeling-based predictions with assumed fibroblast-cardiomyocyte electrical coupling are operative in vivo remains to be determined; in situ validations also are required. In vitro, fibroblast proliferation was enhanced by pharmacological suppression of $K_{v}$ current, suggesting $K_{v}$ channels might negatively regulate fibroblast proliferation. ${ }^{30}$ Although it appears beneficial in terms of presumed

Table 1. Summary of Altered lon Channel Functions in Human and Animal Cardiac Fibroblasts From Different Cardiac Disease Models

\begin{tabular}{|c|c|c|c|}
\hline Species & Ion channel & Condition/model & CF effect \\
\hline \multirow[t]{9}{*}{ Human } & $\mathrm{BK} \mathrm{ca}$ & $\begin{array}{l}\text { Oxidative stress }\left(\mathrm{H}_{2} \mathrm{O}_{2}\right) \\
\text { Normal conditions }\end{array}$ & $\begin{array}{l}\uparrow \text { apoptosis }^{7} \\
\uparrow \downarrow \text { proliferation }^{8}\end{array}$ \\
\hline & TRPA1 & Methylglyoxal (diabetic cardiomyopathy) & $\begin{array}{l}\text { Activation of TRPA } 1 \uparrow \text { proliferation/ } \\
\text { differentiation }^{9}\end{array}$ \\
\hline & Clvol & Inhibition by DIDS & $\downarrow$ proliferation ${ }^{8}$ \\
\hline & $\mathrm{Clca}_{\mathrm{CANO}}$ (A) & Activation by angiotensin II & $\uparrow$ IcICa in atrial $\mathrm{CF}^{10}$ \\
\hline & Ito $\left(K_{v} 4.3\right)$ & $\begin{array}{l}\text { TGF- } \beta 1 \text { activation (atrial) } \\
\text { H2S inhibition (atrial) }\end{array}$ & $\begin{array}{l}\uparrow \text { Ito and differentiation }{ }^{11} \\
\text { Attenuates differentiation }{ }^{11}\end{array}$ \\
\hline & TRPC1 & TGF- $\beta 1$ administration & $\uparrow$ TPRC1 expression ${ }^{12}$ \\
\hline & TRPC6 & TGF- $\beta 1$ treatment & $\uparrow$ TRPC6 expression ${ }^{12}$ \\
\hline & TRPM7 & AF patients, TGF- $\beta 1$ & $\uparrow$ proliferation/differentiation ${ }^{13}$ \\
\hline & $\mathrm{Na}^{+}\left(\mathrm{Na}_{\mathrm{v}} 1.5\right)$ & Atrial fibroblast & $\uparrow$ differentiation ${ }^{14}$ \\
\hline \multirow[t]{2}{*}{ Dogs } & $\mathrm{K}_{\mathrm{v}}$ & Tachypacing-induced HF & $\downarrow \mathrm{K}_{\mathrm{v}}$ currents (atrial CF $)^{15}$ \\
\hline & $K_{\text {ir }}$ & Tachypacing-induced HF & $\uparrow \mathrm{K}_{\text {ir }}$ currents (atrial CF) ${ }^{16}$ \\
\hline \multirow[t]{7}{*}{ Rats } & $\mathrm{IK} \mathrm{Ka}$ & $\begin{array}{l}\text { Pressure overload (aortic constriction) } \\
\text { Angiotensin II administration } \\
\text { Treatment with AGEs }\end{array}$ & $\begin{array}{l}\uparrow \mathrm{IK}_{\mathrm{ca}} \text { currents }^{17} \\
\uparrow \mathrm{IK}_{\mathrm{ca}} \text { expression }^{18} \\
\uparrow \mathrm{IK}_{\mathrm{ca}} \text { expression }^{19}\end{array}$ \\
\hline & TRPC3 & AF, heart failure & $\uparrow$ TRPC3 expression ${ }^{20}$ \\
\hline & TRPM2 & Hypoxia & $\uparrow$ TRPM2 currents ${ }^{21}$ \\
\hline & TRPM7 & $\begin{array}{l}\text { Angiotensin II-induced fibrosis } \\
\text { TGF- } \beta 1 \text { treatment }\end{array}$ & $\begin{array}{l}\text { Initial } \uparrow \text { and later } \downarrow \text { currents }^{22} \\
\uparrow \text { TRPM7 currents/proliferation/ } \\
\text { differentiation }{ }^{22}\end{array}$ \\
\hline & TRPV1 & TGF- $\beta 1$-induced differentiation & $\begin{array}{l}\text { Essential for differentiation; } \uparrow \text { TRPV4 } \\
\text { expression } / \mathrm{Ca}^{2+} \text { influx }{ }^{23}\end{array}$ \\
\hline & $\begin{array}{l}\text { L-type and } \\
\text { T-type } \mathrm{Ca}^{2+}\end{array}$ & TGF- $\beta 1$ treatment & Smad2 phosphorylation ${ }^{24}$ \\
\hline & KatP $\left(\mathrm{K}_{\mathrm{ir}} 6.2\right)$ & Myocardial infarction & $\begin{array}{l}\uparrow \mathrm{K}_{\mathrm{ir} 6.2} \text { expression; affects injury zone } \\
\text { electrophysiology }{ }^{25}\end{array}$ \\
\hline \multirow[t]{3}{*}{ Mice } & $\mathrm{IK} \mathrm{Ka}$ & Myocardial infarction & $\uparrow \mathrm{K}_{\mathrm{ca} 3.1}$ expression and fibrosis ${ }^{26}$ \\
\hline & SUR2/Kir6.1 & Activation by pinacidil & $\begin{array}{l}\uparrow \text { ventricular CF proliferation; } \downarrow \text { IL- } 6 \\
\text { secretion; active in transdifferentiation }{ }^{27}\end{array}$ \\
\hline & TRPC6 & $\begin{array}{l}\text { Ventricular pressure overload } \\
\text { TRPC6-deletion }\end{array}$ & $\begin{array}{l}\downarrow \text { TRPC } 6 \text { expression }{ }^{28} \\
\text { Impaired cardiac wound healing }\end{array}$ \\
\hline
\end{tabular}

AF, atrial fibrillation; AGEs, advanced glycation end products; CF, cardiac fibroblast; DIDS, 4,4'-diisothiocyano-2,2'stilbenedisulfonic acid; HF, heart failure. 
antifibrillatory effect, downregulation of $\mathrm{K}_{\mathrm{v}}$ channels also leads to increased proliferation of fibroblasts, ${ }^{30}$ which can be counter-productive as it can result in increased fibrosis, a substrate for arrhythmogenesis. Thus, the net effect of $\mathrm{CF} \mathrm{K}_{\mathrm{v}}$ channel downregulation/ expression, regulation and pharmacological modulation on overall myocardial function, arrhythmogenesis and scarring needs to be clarified in the normal and diseased heart before any therapeutic strategies targeting $\mathrm{K}_{\mathrm{v}}$ channels can be formulated for limiting myocardial fibrosis.

Ca ${ }^{2+}$-Activated $\mathrm{K}^{+}\left(\boldsymbol{K}_{\text {Ca }}\right)$ Channels: $\mathrm{K}_{\mathrm{Ca}}$ channels are modulated by cytoplasmic free $\mathrm{Ca}^{2+}$ and classified into three subtypes based on their single-channel conductance: big conductance $\left(\mathrm{BK}_{\mathrm{Ca}}\right)$, intermediate conductance $\left(\mathrm{IK}_{\mathrm{Ca}}\right)$, and small conductance $\left(\mathrm{SK}_{\mathrm{Ca}}\right)$. They also vary in their pharmacology, $\mathrm{Ca}^{2+}$ sensitivity and voltage dependence. ${ }^{6}$

$\mathrm{BK}_{\mathrm{Ca}}$ currents were found in most of the human $\mathrm{CFs}^{31}$ and rat ventricular fibroblasts. ${ }^{32}$ These channels positively regulate the cell cycle as their blockade by paxilline suppressed proliferation of human CFs and was mostly arrested at G0/G1 phase with decreased expression of cyclin D1 and cyclin E, ${ }^{8}$ slowing down the cell cycle progression. Interestingly, in conditions associated with oxidative stress, $\mathrm{BK}_{\mathrm{Ca}}$ channels can evoke apoptosis of human CFs. Hydrogen peroxide increases iberiotoxin-sensitive $\mathrm{BK}_{\mathrm{Ca}}$ currents via the protein kinase $\mathrm{G}$ pathway, resulting in apoptotic cell injury. ${ }^{7}$ On one side, $\mathrm{BK}_{\mathrm{Ca}}$ channels promote cell cycle progression; on the other, they can also promote apoptosis in cells under oxidative stress. Thus there appears to be either a dual role played by the $\mathrm{BK}_{\mathrm{Ca}}$ channels themselves or additional molecular signaling mechanisms involving these channels that might become active under stress conditions.

$\mathrm{IK}_{\mathrm{Ca}}$ channels, those of intermediate conductance, are expressed in rat $^{32}$ and mice ${ }^{26}$ ventricular fibroblasts. In a mouse model of myocardial infarction, higher expression of $\mathrm{K}_{\mathrm{Ca}} 3.1$ in ventricular fibroblasts was associated with excessive fibrosis and impaired heart function, ${ }^{26}$ and pharmacological blockade of $\mathrm{K}_{\mathrm{Ca}} 3.1$ by TRAM-34 was shown in a rat model to reduce pressure overload-induced fibrosis, which could be alleviated by in vivo administration of
TRAM-34 for 2 weeks. ${ }^{17}$ These observations suggest that functional activation of $\mathrm{IK}_{\mathrm{Ca}}$ channels promotes cardiac fibrosis; however, its mechanistic basis remains undefined.

Angiotensin II, a vasoactive peptide hormone, also has been shown to increase the expression of $\mathrm{K}_{\mathrm{Ca}} 3.1$ channels via type 1 angiotensin II receptors involving the extracellular signal-regulated kinase $1 / 2$ (Erk1/2), p38 mitogen-activated protein kinase (p38-MAPK) and phosphatidylinositol-3-kinase (PI3K/Akt) signaling mediators with induction of activator protein-1 complex in cultured rat CFs. ${ }^{18}$ In vitro exposure of rat $\mathrm{CFs}$ to advanced glycation end products (AGEs), which are glycated proteins or lipids when exposed to hyperglycemic conditions like diabetes, increases the expression of $\mathrm{K}_{\mathrm{Ca}} 3.1$ channels and promotes fibroblast proliferation and collagen synthesis through AGE receptor signaling via phosphorylation of the Erk1/2, p38-MAPK and PI3K/ Akt signaling mechanisms. ${ }^{19}$ How changes in $\mathrm{K}_{\mathrm{Ca}} 3.1$ gating, which effectively changes plasma membrane polarity, alter the phosphorylation status of signaling molecules in the Erk1/2-Akt pathway is puzzling. In contrast, inhibition of $\mathrm{IK}_{\mathrm{Ca}}$ channels in vitro is reported to increase rat fibroblast proliferation, ${ }^{32}$ similar to $\mathrm{K}_{\mathrm{v}}$ channels in canine $\mathrm{CFs}^{30}$

$\mathrm{SK}_{\mathrm{Ca}}$ channels are expressed in rat ventricular fibroblasts, ${ }^{32}$ however, their physiological importance has yet to be elucidated.

$\boldsymbol{K}_{\text {ir }}$ Channels: These channels belong to the inward rectifier $\mathrm{K}^{+}$channel family and show increased $\mathrm{K}^{+}$ conductance under hyperpolarization (favoring $\mathrm{K}^{+}$influx) and decreased conductance during depolarization. ${ }^{6} \mathrm{~K}_{\text {ir }}$ currents are reported in human $\mathrm{CFs},{ }^{31}$ and $\mathrm{K}_{\mathrm{ir}} 2.1$ appears to be the primary ion channel responsible for maintaining the resting membrane potential of fibroblasts. ${ }^{33} \mathrm{Ba}^{2+}$-sensitive $\mathrm{K}_{\text {ir }}$ currents were upregulated in canine atrial fibroblasts from a tachypacing-induced heart failure model. ${ }^{15}$ Apart from hyperpolarized resting membrane potential, left atrial fibroblasts obtained from dogs with congestive heart failure showed increased $\mathrm{K}_{\text {ir }}$ currents and poreforming subunit KCNJ2 expression at both mRNA and protein levels. ${ }^{16}$ Hyperpolarized membrane potential caused by upregulation of $\mathrm{K}_{\mathrm{ir}}$ channels in 
fibroblasts also can increase the driving force for $\mathrm{Ca}^{2+}$ entry through mechanisms like store-operated $\mathrm{Ca}^{2+}$ entry (SOCE), thereby enhancing intracellular $\mathrm{Ca}^{2+}$-dependent processes like secretion of profibrotic factors, cytokines and collagen as well as promoting fibroblast proliferation and facilitation of many receptor-signaling pathways..$^{16,34,35}$

SUR2/Kir6.1 Channels: Pinacidil-activated glibenclamide-sensitive $\mathrm{K}^{+}$channels, which are insensitive to intracellular adenosine triphosphate (ATP), were found to become functional in mouse ventricular fibroblasts culture when differentiation to myofibroblasts occured. Activation of these currents increases fibroblast proliferation but decreases the secretion of the interleukin- 6 cytokine. ${ }^{27}$ Endogenous phospholipid, sphingosine-1-phosphate also can activate these channels. ${ }^{27}$ The mechanisms by which these channels become functional during the fibroblast transdifferentiation process are not known. ATP-sensitive $\mathrm{K}^{+}$currents $\left(\mathrm{K}_{\mathrm{ir}} 6.2\right)$ are also present in $\mathrm{CFs},{ }^{25}$ however, little is known about their role in cardiac pathology. Attenuation of atrial CF proliferation by sodium hydrogen sulphide (an activator of $\mathrm{K}_{\text {ATP}}$ ) following inhibition of $\mathrm{K}_{\mathrm{ATP}}$ channels by glibenclamide suggests that $\mathrm{K}_{\text {ATP }}$ channels are less likely to play any role, at least regarding proliferation. ${ }^{11}$

$K_{v} 4.3$ Channels: Transient outward $\mathrm{K}^{+}$currents $\left(\mathrm{K}_{\mathrm{v}} 4.3\right)$ are present in human atrial fibroblasts. ${ }^{11}$ TGF$\beta 1$-induced fibroblast proliferation and differentiation seems to be accompanied by increased expression of $\mathrm{K}_{\mathrm{v}} 4.3$, which could be attenuated by preincubation with hydrogen sulphide, an endogenous gaseous modulator of $\mathrm{K}^{+}$channels. ${ }^{11}$ Acute exposure of atrial fibroblasts to hydrogen sulphide facilitates steady-state inactivation of $\mathrm{I}_{\text {to }}$ currents and attenuates recovery from inactivation. ${ }^{11}$ Antagonizing $\mathrm{K}_{\mathrm{v}} 4.3$ channels may be a potential antifibrotic strategy to prevent the progression of fibrosis, thereby decreasing the substrate for cardiac dysfunctions like atrial fibrillation, cardiomyopathy and heart failure.

\section{Calcium $\left(\mathrm{Ca}^{2+}\right)$ Channels}

The $\mathrm{Ca}^{2+}$ ion, a major second messenger in cellular signaling mechanisms, can bind with high affinity to several proteins and change their shape and charge and, consequentially, change the corresponding protein's function. ${ }^{35}$ Several $\mathrm{Ca}^{2+}$ influx mechanisms are found to exist in CFs.

SOCE channels: Store-operated $\mathrm{Ca}^{2+}$ channels are highly $\mathrm{Ca}^{2+}$-selective plasma membrane channels that get activated when endoplasmic reticulum $\left[\mathrm{Ca}^{2+}\right]$ declines. In a canine model of congestive heart failure, left atrial fibroblasts showed increased SOCE and proliferation. ${ }^{16}$ However, the mechanisms involved in the increased SOCE in heart failure atrial fibroblasts are not clear; although, hyperpolarized resting membrane potential with increased $\mathrm{K}_{\mathrm{ir}}$ and enhanced electrical driving force for $\mathrm{Ca}^{2+}$ entry has been suggested as one possible mechanism. ${ }^{16}$ Several SOCE pathways have been suggested, including the $\mathrm{Ca}^{2+}$ release-activated channels (ICRAC) that are comprised of plasmalemmal Orai1, the pore-forming subunit, and STIM1, a regulatory subunit considered to be the endoplasmic reticulum store's $\mathrm{Ca}^{2+}$ sensor. ${ }^{36}$ The relative importance of changes in these subunits in promoting cardiac fibrosis in different pathological conditions is not clearly defined. Aging-related decrease in SOCE and proliferation in rat glomerular mesangial cells has been reported, ${ }^{37}$ provoking interest on SOCE in aged human CFs.

L-and T-type $\boldsymbol{C a}^{2+}$ Channels: These voltage-dependent $\mathrm{Ca}^{2+}$ channels are predominant in excitable cells, where their role in tissue excitability, excitation-contraction coupling or secretion is well characterized. However, despite demonstration of mRNA of the L-type and T-type $\mathrm{Ca}^{2+}$ channels in nonexcitable cells like neonatal rat $\mathrm{CFs},{ }^{24}$ their significance in fibroblast function is not clear. TGF- $\beta 1$-induced phosphorylation of Smad2 was inhibited by combined L- and T-type channel block, while neither L- nor T-type inhibition alone affected the phosphorylation of Smad2. ${ }^{24}$ Further studies with adult animal models and human CFs in physiological and pathological conditions would throw more light on these channels' respective roles in the function of nonexcitable cells.

\section{Transient Receptor Potential (TRP) Channels}

Several mammalian TRP channels have been identified and are classified into six subfamilies based on amino acid sequence homology: TRPC (canonical), TRPM (melastatin), TRPV (vanilloid), TRPA (ankyrin), 
TRPML (mucolipin) and TRPP or PKD (polycystin). ${ }^{38}$ Of these, few types were detected functionally in CFs. A summary of the functional role of various TRP channels in CFs from humans is depicted in Figure 1 and Table 1, the latter of which includes observations from various animal models.

TRPA1 Channels: TRPA1 channels are found to be expressed in human CFs. ${ }^{9}$ Methylglyoxal, an endogenous carbonyl compound produced under hyperglycemic conditions, was found to activate TRPA1 and enhance cell cycle progression and fibroblast differentiation. ${ }^{9}$ Any change in the basal expression or activity levels of TRPA1 channels in the setting of cardiac disease conditions is not presently known. It is probable that alterations are only at the regulatory level of these channels by endogenous ligands like methylglyoxal.

TRPC1 Channels: The TRPC channels permeate for $\mathrm{Ca}^{2+}$ and $\mathrm{Na}^{+}$ion influx. ${ }^{39}$ TGF- $\beta 1$, a profibrotic cytokine shown to be elevated in cardiac tissue post-myocardial infarction, ${ }^{40}$ enhances mRNA/ protein expression of TRPC1 channels in human $\mathrm{CFs},{ }^{12}$ suggesting participation of TRPC1 channels in the cardiac fibrosis process. However, in rat $\mathrm{CF}$ from atria and ventricles, immunohistochemistry with fluorescence labeling against TRPC1 did not detect any TRPC1 expression. ${ }^{41}$ It remains unknown whether the expression of these channels is speciesdependent.

TRPC3 Channels: These channels are expressed in rat CFs. ${ }^{20}$ Angiotensin II-induced $\mathrm{Ca}^{2+}$ influx, proliferation in fibroblasts and differentiation to myofibroblasts were suppressed by the TRPC 3 blocker, pyrazole- 3 . The expression of TRPC3 appears to be regulated by microRNA-26, which has nuclear factor of activated $\mathrm{T}$ cells (NFAT), a $\mathrm{Ca}^{2+}$-responsive transcriptional factor. Binding sites in the $5^{\prime}$ promoter region and NFAT negatively regulated microRNA-26 transcription. Moreover, NFAT activation is increased in fibroblasts from a canine model of atrial fibrillation, ${ }^{20}$ which could downregulate microRNA-26 and result in upregulation of TRPC3 channels in atrial fibrillation conditions. Further studies are warranted to validate this regulatory pathway in human CFs.
TRPC6 Channels: Ventricular fibroblasts are reported to express TRPC6 channels. ${ }^{28}$ A genomewide screen identified TRPC6 as necessary and sufficient for myofibroblast transformation. Fibroblasts lacking TRPC6 did not respond to TGF- $\beta 1$ - or angiotensin II-induced transdifferentiation, and cardiac wound healing was impaired in TRPC6-knockout mice. ${ }^{29}$ The profibrotic ligands TGF- $\beta 1$ and angiotensin II induced TRPC6 expression through p38-MAPK serum response factor signaling via the TRPC6 promoter. Small interfering RNA knockdown of TRPC6 reduced the diacylglycerol analogue OAG-, thapsigargin- and angiotensin II-induced $\mathrm{Ca}^{2+}$ entry in human CFs. ${ }^{12}$ TGF- $\beta 1$ enhances mRNA/protein expression of TRPC6 channels, ${ }^{12}$ which mediate TGF- $\beta 1$-induced myofibroblast transformation, along with the calcineurin pathway. These TRPCmediated $\mathrm{Ca}^{2+}$ influx pathways were suggested to activate the reverse-mode $\left(\mathrm{Ca}^{2+}\right.$ influx $) \mathrm{Na}^{+} / \mathrm{Ca}^{2+}$ exchanger as well. ${ }^{12}$ In a mouse model of right ventricular pressure overload, suppression of the activity of endoglin, a co-receptor of TGF- $\beta 1$, attenuated TPRC6 activation and reversed cardiac fibrosis. ${ }^{28}$ This also suggests that TRPC6 may be one of the terminal signaling mechanisms of the TGF- $\beta 1$ pathway, which plays an important part in the progression of cardiac fibrosis. Several G proteincoupled receptors regulating activation of TRPC6 also has been reported. Endothelin-1 upregulates TPRC6 channels in neonatal rat $\mathrm{CFs}$ via $\mathrm{G}_{\alpha 12 / 13}$, causing sustained $\mathrm{Ca}^{2+}$ influx and NFAT activation, which, in turn, negatively influences myofibroblast differentiation. ${ }^{42} \mathrm{C}$-type natriuretic peptide activates TPRC6 channels through natriuretic peptide receptor $\mathrm{C}$ via Gi- and phospholipase C-dependent signaling. ${ }^{43}$

TRPM2 Channels: TRPM2 channels are functionally expressed in rat CFs. ${ }^{21}$ Hypoxia enhances TRPM2 expression and increased clotrimazole-sensitive (considered an inhibitor of the TRPM2 channel) currents in cultured fibroblasts from an adult rat heart. The functional status of TRPM2 channels in human CF during hypoxic conditions like myocardial ischemia or infarction has to be elucidated to determine the translational significance of in vitro hypoxic experimental observations. 
TRPM7 Channel: The TRPM7 channel is a nonselective cation channel permeable to both $\mathrm{Ca}^{2+}$ and $\mathrm{Mg}^{2+}$. Human atrial ${ }^{13}$ and rat $\mathrm{CFs}^{22}$ demonstrated ionic currents with electrical and biophysical properties of TRPM7 channels. Angiotensin II-induced proliferation, apoptosis and fibrosis was associated with a timedependent initial increase — and later fall — of TRPM7 currents. ${ }^{22}$ TRPM7 protein expression increases by 24 hours in the presence of angiotensin II. ${ }^{44}$ Silencing TRPM7 channels by short hairpin RNA interference reduced hydrogen peroxide-induced activation of $\mathrm{Ca}^{2+}$ influx and 2-aminoethoxydiphenylborate, a TRPM7 blocker that could inhibit hydrogen peroxide-induced cardiac fibrosis. ${ }^{28}$ In addition to $\mathrm{Ca}^{2+}$, another permeant ion, $\mathrm{Mg}^{2+}$ - an essential cofactor in numerous enzymatic reactions via $\mathrm{Mg}^{2+}$-dependent regulation of MAPK, tyrosine kinases, reactive oxygen species and important signaling molecules — is involved in cell proliferation, differentiation, inflammation, etc. ${ }^{45}$ TRPM7 channels, negatively regulated by the endogenous phospholipid sphingosine, ${ }^{46}$ are increased in atrial fibrillation patients and in vitro TGF- $\beta 1$-induced proliferation and differentiation to myofibroblasts. $^{13}$

TRPV1 Channels: Angiotensin II-induced proliferation of mouse CFs was attenuated by dietary capsaicin, a TRPV1 agonist, unlike in TRPV1-knockout mice. ${ }^{47}$ Activation of TRPV1 channels appears to be beneficial in cardiac hypertrophy and results in reduced fibrosis; however, the underlying mechanism remains unclear. In an earlier study with a TRPV1-null mutant mice model of myocardial infarction, ${ }^{48}$ TRPV1 ablation showed upregulation of TGF- $\beta 1$, MMP-2, Smad2 and collagen expression, with reduced left ventricular ejection fraction and increased end-diastolic and systolic diameters. Activation of TRPV1 expressed in afferent nerve endings of the heart has been shown to be beneficial to cardiac function following myocardial infarction..$^{48}$ This is interesting, as activation of afferent nerve (TRPV1) signaling transmitted centrally to the brain with a feedback efferent signal may help contribute to the preservation of cardiac function after myocardial infarction.

TRPV4 Channels: Functional TRPV4 channels were evident in rat CFs. ${ }^{49} 4 \alpha$-phorbol 12,13-didecanoate, a selective TRPV4 agonist, was able to increase the $\left[\mathrm{Ca}^{2+}\right]_{\mathrm{i}}$ by ruthenium redsensitive $\mathrm{Ca}^{2+}$ influx. ${ }^{49}$ TRPV4, considered to be a mechanosensitive channel, is required for TGF- $\beta 1$ induced differentiation of CFs into myofibroblasts. $\mathrm{Ca}^{2+}$ influx via TRPV4 channels is enhanced, with increased expression of TRPV4 channels observed following TGF- $\beta 1$ treatment. ${ }^{23}$ Mechanosensitivity of TRPV4 channels could play an important role in cardiac remodeling, with altered chamber stiffness resulting from increased differentiation of fibroblasts to myofibroblasts that can further promote cardiac fibrosis. More information on the physiological and pathological role of TRPV4 channels in the cardiovascular system is reported in a recent review by Randhawa et al. ${ }^{50}$

\section{Sodium ( $\left.\mathrm{Na}^{+}\right)$Channels}

$N a_{v} 1.5$ (Tetrodotoxin [TTX]-Resistant) Channel: Differentiated myofibroblasts from human atria displayed fast inward voltage-gated $\mathrm{Na}^{+}$current, which was not detectable in undifferentiated atrial fibroblasts ${ }^{14}$ with a large window current for potentials between -100 and $-20 \mathrm{mV}^{14}$ Interestingly, this $\mathrm{Na}_{\mathrm{v}} 1.5$ channel expression was demonstrated to be a de novo synthesis process during the myofibroblast differentiation ${ }^{14}$ (Figure 1 and Table 1). An earlier study showed rapidly inactivating TTX-resistant $\mathrm{Na}^{+}$ currents even in undifferentiated cultured human $\mathrm{CFs},{ }^{31}$ which could be due to differences in culture method/time, as differentiation can happen by prolonged culture/passage.

TTX-Sensitive $\mathrm{Na}^{+}$Channel: A slow, inactivated $\mathrm{Na}^{+}$ current with a persistent component sensitive to TTX is also reported in human $\mathrm{CFs},{ }^{31}$ however its functional role in $\mathrm{CF}$ under normal or disease conditions has yet to be elucidated.

\section{Chloride ( $\left.\mathrm{Cl}^{-}\right)$Channels}

$\mathrm{Cl}^{-}$, the mostabundant physiological anion - distributed as $\left[\mathrm{Cl}^{-}\right]_{i}<\left[\mathrm{Cl}^{-}\right]_{\mathrm{o}}$ with equilibrium potential $\mathrm{ECl}$ near the resting membrane potential - is involved in regulation of intracellular $\mathrm{pH}$, cell volume and secretion of fluids. ${ }^{6}$ Based on activation mechanisms, there are four classes of $\mathrm{Cl}^{-}$channels: those activated by $\left[\mathrm{Ca}^{2+}\right]_{i}$ elevation, membrane hyperpolarization, cell swelling or cAMPdependent phosphorylation, ${ }^{6}$ with only few studied in CFs. 
Calcium-Dependent $\mathrm{Cl}^{-}$Channels (I CICa) : Human atrial fibroblasts were shown to have channels with properties of calcium-dependent chloride channels, activated by angiotensin II through its type 1 receptors. ${ }^{10}$ It appears that anoctamin-1, a transmembrane protein, ${ }^{51}$ contributes to this $\mathrm{I}_{\mathrm{CICa}}$ current. ${ }^{10}$

Volume-Sensitive Cl Current (I $\left.I_{C, v o l}\right)$ : Blockade of $\mathrm{I}_{\mathrm{Cl} \text {.vol }}$ with $100-200 \mu \mathrm{M}$ of 4,4'-diisothiocyanatostilbene2,2'-disulfonic acid disodium (DIDS) significantly reduced proliferation in human $\mathrm{CFs},{ }^{8}$ with cells predominantly arrested at $\mathrm{G} 0 / \mathrm{G} 1$ phase and associated with decreased cyclin D1 and cyclin E expressions. $^{8}$

\section{Conclusions and Future Directions}

Several different ion channels expressed in cardiac fibroblasts regulate cellular functions under normal and diseased conditions and contribute to fibrosis and arrhythmogenesis. The role of some of these channels, such as TRPC1, TRPC6, TRPM7 and $\mathrm{Na}^{+}$channels, in human $\mathrm{CF}$ proliferation and differentiation as well as $\mathrm{BK}_{\mathrm{Ca}}$ channel in fibroblast proliferation or apoptosis (depending on metabolic state), has been demonstrated; yet, several questions remain unanswered. Although TRPC6 is reported to be necessary and sufficient for myofibroblast transformation, ${ }^{29}$ the existence of other TRP channels, and their activation resulting in the same effect, is puzzling. Whether there is any crosstalk between these channels or any intermediary signaling mechanisms to coordinate the function is unclear. Activation of most TRP channels increases intracellular $\left[\mathrm{Ca}^{2+}\right]$, which can influence multiple signaling mechanisms - including activation of $\mathrm{BK}_{\mathrm{Ca}}, \mathrm{Cl}^{-}$, and intracellular $\mathrm{Ca}^{2+}$ release - which in turn could modulate various cellular functions like proliferation, gene transcription and secretion.

Human studies indicate that the functional effect of ion channel alterations may depend on the cellular metabolic stress, as in the redox state of CFs (e.g. pro-apoptotic vs pro-proliferative effect of $\mathrm{BK}$ Ca channels). Therefore, defining the potential role of each ion channel in CF function remains challenging and needs to be carefully elucidated under various pathophysiological conditions that are further compromised by aging and disease (hyperglycemia, pressure or volume overload, metabolic stress, etc.) before they can be considered as potential targets for the prevention of adverse cardiac remodeling and progression of cardiac dysfunction.

\section{Patient-Friendly Recap}

- As people age, their heart tissue gradually becomes scarred due to the ability of fibroblast cells to heal heart injury.

- Unfortunately, too much scarring eventually contributes to heart dysfunction so cardiac fibroblasts may need to be slowed or deactivated in older patients.

- The authors reviewed the literature to further understand the role certain proteins called ion channels play on cardiac fibroblast production under various states of health.

- A better understanding of these ion channels could lead to novel therapies that limit heart scarring.

\section{Conflicts of interest}

None.

\section{Funding Sources}

This work was supported by an intramural Aurora Cardiovascular Surgical Research Award (to Gracious Ross) funded by the Aurora Health Care Foundation.

\section{References}

1. North BJ, Sinclair DA. The intersection between aging and cardiovascular disease. Circ Res. 2012;110:1097-108. CrossRef

2. Biernacka A, Frangogiannis NG. Aging and cardiac fibrosis. Aging Dis. 2011;2:158-73.

3. Walsh KB, Zhang J. Neonatal rat cardiac fibroblasts express three types of voltage-gated $\mathrm{K}+$ channels: regulation of a transient outward current by protein kinase C. Am J Physiol Heart Circ Physiol. 2008;294:H1010-7. CrossRef

4. Hinz B, Phan SH, Thannickal VJ, Galli A, Bochaton-Piallat ML, Gabbiani G. The myofibroblast: one function, multiple origins. Am J Pathol. 2007;170:1807-16. CrossRef

5. Travers JG, Kamal FA, Robbins J, Yutzey KE, Blaxall BC. Cardiac fibrosis: the fibroblast awakens. Circ Res. 2016;118:1021-40. CrossRef

6. Hille B. Ion Channels of Excitable Membranes, Third Edition. Sunderland, MA: Sinauer Associates, 2001. 
7. Bae H, Lee D, Kim YW, et al. Effects of hydrogen peroxide on voltage-dependent $\mathrm{K}(+)$ currents in human cardiac fibroblasts through protein kinase pathways. Korean $J$ Physiol Pharmacol. 2016;20:315-24. CrossRef

8. He ML, Liu WJ, Sun HY, et al. Effects of ion channels on proliferation in cultured human cardiac fibroblasts. $J \mathrm{Mol}$ Cell Cardiol. 2011;51:198-206. CrossRef

9. Oguri G, Nakajima T, Yamamoto Y, et al. Effects of methylglyoxal on human cardiac fibroblast: roles of transient receptor potential ankyrin 1 (TRPA1) channels. Am J Physiol Heart Circ Physiol. 2014;307:H1339-52. CrossRef

10. El Chemaly A, Norez C, Magaud C, et al. ANO1 contributes to angiotensin-II-activated $\mathrm{Ca} 2+$-dependent $\mathrm{Cl}$ - current in human atrial fibroblasts. J Mol Cell Cardiol. 2014;68:12-9. CrossRef

11. Sheng J, Shim W, Wei H, et al. Hydrogen sulphide suppresses human atrial fibroblast proliferation and transformation to myofibroblasts. J Cell Mol Med. 2013;17:1345-54. CrossRef

12. Ikeda K, Nakajima T, Yamamoto Y, et al. Roles of transient receptor potential canonical (TRPC) channels and reversemode $\mathrm{Na}+/ \mathrm{Ca} 2+$ exchanger on cell proliferation in human cardiac fibroblasts: effects of transforming growth factor beta1. Cell Calcium. 2013;54:213-25. CrossRef

13. Du J, Xie J, Zhang Z, et al. TRPM7-mediated Ca2+ signals confer fibrogenesis in human atrial fibrillation. Circ Res. 2010;106:992-1003. CrossRef

14. Chatelier A, Mercier A, Tremblier B, et al. A distinct de novo expression of Nav1.5 sodium channels in human atrial fibroblasts differentiated into myofibroblasts. $J$ Physiol. 2012;590:4307-19. CrossRef

15. Aguilar M, Qi XY, Huang H, Comtois P, Nattel S. Fibroblast electrical remodeling in heart failure and potential effects on atrial fibrillation. Biophys J. 2014;107:2444-55. CrossRef

16. Qi XY, Huang H, Ordog B, et al. Fibroblast inward-rectifier potassium current upregulation in profibrillatory atrial remodeling. Circ Res. 2015;116:836-45. CrossRef

17. Zhao LM, Wang LP, Wang HF, Ma XZ, Zhou DX, Deng XL. The role of $\mathrm{KCa} 3.1$ channels in cardiac fibrosis induced by pressure overload in rats. Pflugers Arch. 2015;467:2275-85. CrossRef

18. Wang LP, Wang Y, Zhao LM, Li GR, Deng XL. Angiotensin II upregulates $\mathrm{K}(\mathrm{Ca}) 3.1$ channels and stimulatescellproliferation in rat cardiac fibroblasts. Biochem Pharmacol. 2013;85: 1486-94. CrossRef

19. Zhao LM, Zhang W, Wang LP, Li GR, Deng XL. Advanced glycation end products promote proliferation of cardiac fibroblasts by upregulation of KCa3.1 channels. Pflugers Arch. 2012;464:613-21. CrossRef

20. Harada M, Luo X, Qi XY, et al. Transient receptor potential canonical-3 channel-dependent fibroblast regulation in atrial fibrillation. Circulation. 2012;126:2051-64. CrossRef

21. Takahashi K, Sakamoto K, Kimura J. Hypoxic stress induces transient receptor potential melastatin 2 (TRPM2) channel expression in adult rat cardiac fibroblasts. $J$ Pharmacol Sci. 2012;118:186-97. CrossRef

22. Zhou Y, Yi X, Wang T, Li M. Effects of angiotensin II on transient receptor potential melastatin 7 channel function in cardiac fibroblasts. Exp Ther Med. 2015;9:2008-12. CrossRef
23. Adapala RK, Thoppil RJ, Luther DJ, et al. TRPV4 channels mediate cardiac fibroblast differentiation by integrating mechanical and soluble signals. $J \mathrm{Mol}$ Cell Cardiol. 2013;54:45-52. CrossRef

24. Lei B, Hitomi H, Mori T, et al. Effect of efonidipine on TGFbeta1-induced cardiac fibrosis through Smad2-dependent pathway in rat cardiac fibroblasts. $J$ Pharmacol Sci. 2011;117:98-105.

25. Benamer N, Vasquez C, Mahoney VM, Steinhardt MJ, Coetzee WA, Morley GE. Fibroblast KATP currents modulate myocyte electrophysiology in infarcted hearts. Am J Physiol Heart Circ Physiol. 2013;304:H1231-9. CrossRef

26. Ju CH, Wang XP, Gao CY, Zhang SX, Ma XH, Liu C. Blockade of $\mathrm{KCa} 3.1$ attenuates left ventricular remodeling after experimental myocardial infarction. Cell Physiol Biochem. 2015;36:1305-15. CrossRef

27. Benamer N, Moha Ou Maati H, Demolombe S, et al. Molecular and functional characterization of a new potassium conductance in mouse ventricular fibroblasts. $J \mathrm{Mol}$ Cell Cardiol. 2009;46:508-17. CrossRef

28. Kapur NK, Qiao X, Paruchuri V, et al. Reducing endoglin activity limits calcineurin and TRPC-6 expression and improves survival in a mouse model of right ventricular pressure overload. J Am Heart Assoc. 2014;3(4):e000965. CrossRef

29. Davis J, Burr AR, Davis GF, Birnbaumer L, Molkentin JD. A TRPC6-dependent pathway for myofibroblast transdifferentiation and wound healing in vivo. Dev Cell. 2012;23:705-15. CrossRef

30. Wu CT, Qi XY, Huang H, et al. Disease and region-related cardiac fibroblast potassium current variations and potential functional significance. Cardiovasc Res. 2014;102:487-96. CrossRef

31. Li GR, Sun HY, Chen JB, Zhou Y, Tse HF, Lau CP. Characterization of multiple ion channels in cultured human cardiac fibroblasts. PLoS One. 2009;4(10):e7307. CrossRef

32. Choi S, Lee W, Yun J, Seo J, Lim I. Expression of Ca-activated $\mathrm{K}$ channels and their role in proliferation of rat cardiac fibroblasts. Korean J Physiol Pharmacol. 2008;12:51-8. CrossRef

33. Chilton L, Ohya S, Freed D, et al. K+ currents regulate the resting membrane potential, proliferation, and contractile responses in ventricular fibroblasts and myofibroblasts. Am J Physiol Heart Circ Physiol. 2005;288:H2931-9. CrossRef

34. Penna A, Stutzin A. KCa3.1-dependent hyperpolarization enhances intracellular $\mathrm{Ca} 2+$ signaling induced by $\mathrm{AMLF}$ in differentiated U937 cells. PLoS One. 2015;10:e139243. CrossRef

35. Clapham DE. Calcium signaling. Cell. 2007;131:1047-58. CrossRef

36. Prakriya M, Feske S, Gwack Y, Srikanth S, Rao A, Hogan PG. Orail is an essential pore subunit of the CRAC channel. Nature. 2006;443:230-3. CrossRef

37. Shen B, Zhu J, Zhang J, et al. Attenuated mesangial cell proliferation related to store-operated $\mathrm{Ca} 2+$ entry in aged rat: the role of STIM 1 and Orai 1. Age (Dordr). 2013;35:2193202. CrossRef

38. Wu LJ, Sweet TB, Clapham DE. International Union of Basic and Clinical Pharmacology. LXXVI. Current progress in the mammalian TRP ion channel family. Pharmacol Rev. 2010;62:381-404. CrossRef 
39. Bon RS, Beech DJ. In pursuit of small molecule chemistry for calcium-permeable non-selective TRPC channels - mirage or pot of gold? Br J Pharmacol. 2013;170:459-74. CrossRef

40. Khan SA, Joyce J, Tsuda T. Quantification of active and total transforming growth factor-beta levels in serum and solid organ tissues by bioassay. BMC Res Notes. 2012;5:636. CrossRef

41. Huang $\mathrm{H}$, Wang $\mathrm{W}$, Liu P, et al. TRPC1 expression and distribution in rat hearts. Eur $J$ Histochem. 2009;53:e26. CrossRef

42. Nishida M, Onohara N, Sato Y, et al. Galpha12/13-mediated up-regulation of TRPC6 negatively regulates endothelin1 -induced cardiac myofibroblast formation and collagen synthesis through nuclear factor of activated $\mathrm{T}$ cells activation. J Biol Chem. 2007;282:23117-28.

43. Rose RA, Giles WR. Natriuretic peptide $\mathrm{C}$ receptor signalling in the heart and vasculature. $J$ Physiol. 2008;586:353-66. CrossRef

44. Yu Y, Chen S, Xiao C, et al. TRPM7 is involved in angiotensin II induced cardiac fibrosis development by mediating calcium and magnesium influx. Cell Calcium. 2014;55:25260. $\underline{\text { CrossRef }}$

45. Touyz RM, Yao G. Up-regulation of vascular and renal mitogen-activated protein kinases in hypertensive rats is normalized by inhibitors of the $\mathrm{Na}+\mathrm{Mg} 2+$ exchanger. Clin Sci (Lond). 2003;105:235-42. CrossRef
46. Qin X, Yue Z, Sun B, et al. Sphingosine and FTY720 are potent inhibitors of the transient receptor potential melastatin 7 (TRPM7) channels. Br J Pharmacol. 2013;168:1294-312. CrossRef

47. Wang Q, Ma S, Li D, et al. Dietary capsaicin ameliorates pressure overload-induced cardiac hypertrophy and fibrosis through the transient receptor potential vanilloid type $1 . \mathrm{Am}$ J Hypertens. 2014;27:1521-9. CrossRef

48. Huang W, Rubinstein J, Prieto AR, Wang DH. Enhanced postmyocardial infarction fibrosis via stimulation of the transforming growth factor-beta-Smad2 signaling pathway: role of transient receptor potential vanilloid type 1 channels. J Hypertens. 2010;28:367-76. CrossRef

49. Hatano N, Itoh $\mathrm{Y}$, Muraki K. Cardiac fibroblasts have functional TRPV4 activated by 4alpha-phorbol 12,13-didecanoate. Life Sci. 2009;85:808-14. CrossRef

50. Randhawa PK, Jaggi AS. TRPV4 channels: physiological and pathological role in cardiovascular system. Basic Res Cardiol. 2015;110:54. CrossRef

51. Kunzelmann K, Tian Y, Martins JR, et al. Anoctamins. Pflugers Arch. 2011;462:195-208. CrossRef

(C) 2016 Aurora Health Care, Inc. 